\title{
Role Model has Impact on Fan's Social view, Political view, educational level, motivation and thoughts
}

\author{
Kausar Yasmeen (Corresponding author) \\ Department of Economics, The Islamia University of Bahawalpur, Pakistan \\ Ph: +92 300899 5083, Email: eco.yasmeen@gmail.com \\ Ambreen Anjum \\ Department of Applied Psychology, The Islamia University of Bahawalpur, Pakistan \\ E-mail: aambreenaanjum@hotmail.com \\ Kashifa Yasmeen \\ Department of Applied Psychology, The Islamia University of Bahawalpur, Pakistan \\ Ph: +92 300772 2474, E-mail: kahsifa.hasan@yahoo.com
}

Received: July 18, 2011 Accepted: August 11, $2011 \quad$ DOI: 10.5296/ijim.v1i1.861

\begin{abstract}
The aim of this study is to evaluate the impact of role model upon fan's social view, political view, educational level, motivation and thoughts. Results of this study are drawn through a survey where Fatima Bhutto is taken as a role model and her fans are included in the survey, the descriptive analysis is used to find out the results. Research results proves that an ideal personality changes our thoughts, believes and ideas regarding our social, political, educational and motivational decisions.
\end{abstract}

Keywords: Ideal personality, fans, role model, social views 


\section{Introduction}

Despite the limited amount of evidence available to support the commonly held belief that role model demonstrable positive effect on the individuals and community. It is not compulsory that role models are not always positive; they can be seen to promote negative social images as well, beliefs and behaviors etc. This can apply equally to teachers, film actress, writer, poet, actress, political leaders, teachers and parents as it can apply to celebrities and athletes

When we were babies, we had no identity except that given to us by our parents. Later, this sense of identity was added to by the hopes, fears and expectations of others. In our learned behaviour for survival, we learned to develop attachments to those things which raised our approval rating in the eyes of our support network - parents, religion - society. From this conditioning environment we learned a meaning of love that was not unconditional, so at that time we were following parents so parents were role model. Mac Callum and Beltman (2002) have identified the general characteristics of successful role model programs he highlights role model are source of learning.

The role models who influence children and adolescents tend to change over time (Glover, 1978). Early in life, young children refer to their immediate family members, to provide positive attitudes and behaviors. Up to the age of five, parental influence may have the greatest impact. At school, the principal role models change from family members to friends and teachers and as the child continues to get older, his/her role models begin to originate from a range of other areas including athletes, coaches, television stars, pop stars and movie stars (French \& Pena, 1991). Parents, friends and teachers may still be seen as role models during the adolescent and adult years, especially for females. The following section provides a review of the literature associated with the role model preferences of young people.

\section{Literature Review}

Such people as teachers, spouses, parents, peers and sporting heroes may be considered as role models. Further, the concept of mentoring and heroes are included within the scope of this definition as a role model and ideal personalities. The mentor shares knowledge, experiences and provides advice to the mentee that purpose to facilitate career development and hike future opportunities (Starcevich, 1998). The term "hero" is frequently used in the place of, or to elaborate, role models and originates from the Greek word meaning, "person distinguished for courage, fortitude or deeds, its meaning is adaptable between cultures and through time etc" (Lines, 2001, p. 287). It is very important to note, that role modeling, including mentoring and heroes, should not be assumed to be solely positive in nature and that the person is worthy of imitation, that why they may influence non-participation or deviant behaviors.

Glover (1978) highlighted especially during the child's early years, the parents, provide the most important role models.(Brustad, 1996)Three main reasons for this are as follows: the child spends the majority of his/her time with the family and household; young children lack the social skills to establish networks outside of the family and house hold; and young 
children rely heavily on the feed back of parents in connecting of assessing competency.

\subsection{Theoretical Perspectives of Role Modeling are following:}

\subsubsection{Social Cognitive Theory}

This theory evolved from the original work of Bandura (1977).Bandura (1977) highlighted in his earlier work, that the mission of learning would be a most tedious mission if there was reliance solely on the effects of the learner's own actions. Mostly learned from observation and hence relies to a large extent on the influence of role models as well. Basically there are four processes attached to social leaning, which are following:

Attention processes: Learning will not occur unless the learner attends very closely to the role model and perceives specific clues accurately. Such type of learning is subsequently mediated through factors such as role model characteristics, observer characteristics and features of the modeled behavior and actions. In the first instance, target models may impact learners through such features as attractiveness, status, competence and similarity. Secondly, the learner's characteristics such as race, gender, socio-economic status may also be very important. Consequently, the model's method of behavior presentation is particularly essential.

Retention processes: lack of the recollection, the observation process becomes meaningless. If, the retention process is assisted greatly by the medium of symbols which may be represented by two systems, namely images and words as well. Sensory stimulation conclusion in perceptions of events which, through are repeated exposure, begin to be associated with the certain images.

Motor reproduction processes: This is a process of converting symbolic representations into the required behavioral actions. The actual act of on behalf of a model's behaviour involves cognitive organization of responses, initiation, monitoring and refining. Not all details are embraced by the learner in the first excursion with a new skill, but an approximation results which may then be refined with reinforcement of input cues.

Motivational processes: enact a modeled behavior also depends on the wish to commit. Usually, if the consequences of the behavior are deemed to be precious or rewarding somewhat than negative in upshot, then the there will be a superior incentive to perform that behavior.

\subsubsection{Self-Efficacy Theory}

The effectiveness of models to influence learners to a carry out a particular sort of behavior may also be reliant on the characteristics of these models (Bandura, 1997). If a role model is similar, rather than disparate, to a learner and demonstrates an exceedingly skilled activity, there is more chance for the learner and fans to be motivated. In this connection there are three mediating factors associated with this theory:

Self-efficacy expectancy: This is related about the learners' perceptions of how able they feel they are to in fact carry out the behavior. 
Outcome expectancy: If there is a high probability that the behavior will consequence in the particular result, there is a greater chance that the learner will accept the behavior.

Outcome value: If the result of the behavior is wanted then there is a greater chance of the behavior being undertaken.

\subsubsection{Social Context Framework}

Whereas prior theoretical frameworks have paying attention on observations and a cognitive factor linked with the learner, another approach which may be mainly effective is one in which there is considerably bigger interaction between the role model and the learner. Such an approach is maybe more well-matched to the process of mentoring and as Galbraith and Cohen (cited in Kerka, 1998) has highlighted "The idea of learning a transaction - an interactive and developing process between mentors and their learners - is consider is a fundamental factor of the adult mentoring relationship”

Above theoretical frameworks proves that observation, cognition and interaction are the ways of learning through role models which impact on the life of fans.

\section{Statement of the Problem}

When fan idealize someone personality fan become learner and ideal personality play a role of role model and effect on the above indicators of the model. For instance first learner was conservative about political freedom, now if his role model is interested in political freedom when role model will talk in favor of political freedom with logics and references' it will change the fan's view about political view. The same case will happen with other indicator captioned above.

\section{Objectives of Research}

1. Is Role model change political view, social life, motivation, level of education and thinking?

2. To check, if role model is man of quality give positive results and if role model is man of bad quality give negative results.

3. To purpose suggestions to decrease and improve familiarity of role model, it's up to role model; he/she is a good or bad man of quality to save fans.

\section{Methodology and Tools of Data Collection}

Descriptive analysis has used to find out the results Two types of qualitative as well as quantitative questionnaires have done by two types of persons mentioned below;

A. First has been filled by role model's fans.

B. Second has been filled by common persons, who are not of role model Fatima Bhutto's fan.

300 Questionnaire, 150 by Fatima Bhutto's fan and 150 by common individual were filled through E-mail, telephonic conversation and direct interview, face book etc. 


\section{Role Model's Impact on Fans.}

We first provide descriptive analysis as in order to get insight about the impact of role model on Fans.

\subsection{Descriptive analysis}

We present descriptive analysis in the form of Tables

\begin{tabular}{|l|l|l|l|l|l|}
\hline \multirow{2}{*}{ Change in indicators } & \multicolumn{4}{l}{ Answer common individual and Fatima's fan } \\
\cline { 2 - 6 } & $\mathrm{x} 1$ edu & $\mathrm{x} 2$,med & $\mathrm{x} 3$,occu & $\mathrm{x} 4$,FB & $\mathrm{x} 5$,Other \\
\hline Change in political thoughts & $30 \%$ & $21 \%$ & $7 \%$ & $40 \%$ & $02 \%$ \\
\hline Change in social life & $35 \%$ & $30 \%$ & $21 \%$ & $30 \%$ & $06 \%$ \\
\hline Change in educational level & $19 \%$ & $21 \%$ & $05 \%$ & $10 \%$ & 45 \\
\hline Change in motivation & $14 \%$ & $23 \%$ & $10 \%$ & $50 \%$ & $03 \%$ \\
\hline Change in thoughts & $37 \%$ & $27 \%$ & $09 \%$ & $40 \%$ & $05 \%$ \\
\hline
\end{tabular}

Source: Survey

$\mathrm{X}_{1}=$ education, $\mathrm{X}_{2}=$ media, $\mathrm{X}_{3}=$ occupation, $\mathrm{X}_{4}=$ Fatima Bhutto and $\mathrm{X}_{5}=$ others.

The table sited above elaborate the impact of role model on fan.30\% individual answer that change in their political view is just because of education,21\% reply that media has changed their political view, occupation brought change in political thought of $07 \%$,while $40 \%$ individual response was that because of their role model they have change their political views. This proves that role model influence fans life.

The table sited above elaborate the impact of role model on fan.35\% individual answer that change in their social life is just because of education, $30 \%$ said it is because of media which brought change in their social life through awareness, occupation brought change in political thought of $21 \%$, while $30 \%$ individual response was that because of their role model they have change their political views. This proves that role model influence fans life.06\% answered that this change is because of other reasons.

The table sited above elaborate the impact of role model on fan.37\% individual answer that change in their thoughts is just because of education,27\% reply that media has changed their thoughts, occupation brought change in thoughts of $09 \%$, while $40 \%$ individual response was that because of their role model they have change their Change thoughts. This proves that role model influence fans life $05 \%$ individual that Change in thoughts is because of other reasons.

The table sited above elaborate the impact of role model on fan.19\% individual answer that change in their Change in educational level is just because of education, 21\% reply that media has changed their Change in educational level, occupation brought change in Change 
in educational level of $05 \%$, while $10 \%$ individual response was that because of their role model they have change their Change in educational level. This proves that role model influence fans life $5 \%$ individual that change in education is because of other reasons.

The table sited above elaborate the impact of role model on fan.14\% individual answer that change in their motivation is just because of education,23\% reply that media has changed their motivation, occupation brought change in Change in motivation of $10 \%$, while $50 \%$ individual response was that because of their role model they have change their Change in motivation. This proves that role model influence fans life 03\% individual that Change in motivation is because of other reasons. So role model and fan have positive relation as (McCauley \& Mihalko, 1998) said a model is similar, rather than dissimilar, to a learner and demonstrates a highly skilled activity, there is more chance for the learner to be motivated. This type of behavioral mechanism can be associated with Bandera's self-efficacy theory which is a competency based theory that has been applied to over 100 studies

The table sited above elaborates the impact of role model on fan. $37 \%$ individual answer that change in their thoughts is just because of education,27\% reply that media has changed their thoughts, occupation brought change in thoughts of $09 \%$,while $40 \%$ individual response was that because of their role model they have change their Change thoughts. This proves that role model influence fans life $05 \%$ individual that Change in thoughts is because of other reasons.

\section{A. Role Model's qualities little bit matches with their fans,}

\section{B. Role model is man of quality give positive results and if role model is man of bad quality gives negative results.}

The two personalities were taken as a role model Fatima Bhutto and Altaf Hussain both are from Pakistan, according general reputation through media, internet etc; Fatima has more positively personality comparatively.

Table: $a$

\begin{tabular}{|l|l|l|l|}
\hline \multirow{2}{*}{ Sr. no } & Questions & \multicolumn{2}{l|}{ Response by Fatima Bhutto's fan } \\
\cline { 3 - 4 } & & 0 & 1 \\
\hline 1 & To get political right which way should implement? & $60 \%$ & $40 \%$ \\
\hline 2 & Get social benefit which way is better? & $61 \%$ & $39 \%$ \\
\hline 3 & Should we Rise voice against violence & $73 \%$ & $27 \%$ \\
\hline 4 & Are Short cut for success better by little bit wrong way? & $40 \%$ & $60 \%$ \\
\hline 5 & Is forgive best way? & $21 \%$ & $79 \%$ \\
\hline
\end{tabular}


Table: $b$

\begin{tabular}{|l|l|l|l|}
\hline \multirow{2}{*}{ Sr. no } & Questions & \multicolumn{2}{l|}{ Response by Hamid Karzai } \\
\cline { 3 - 4 } & & 0 & 1 \\
\hline 1 & To get political right which way should implement? & $61 \%$ & $39 \%$ \\
\hline 2 & Get social benefit which way is better? & $30 \%$ & $70 \%$ \\
\hline 3 & Should we Rise voice against violence & $68 \%$ & $27 \%$ \\
\hline 4 & Are Short cut for success better by little bit wrong & $18 \%$ & $19 \%$ \\
\hline 5 & way? & & \\
\hline
\end{tabular}

0 = by court, justice ----- positive

$1=$ no justice in court use unfair mean, unfair mean -----Negative.

Hamid Karzai, born 24 December 1957 and now he is current President of Afghanistan, taking office on 7 December 2004. He became a dominant political figure after the removal of the Taliban regime in late 2001.Hamid Karzai was the declared winner and became President of the Islamic Republic of Afghanistan. He won a second five-year-term in the 2009 presidential election as well. (www.wekipedia.com)

The questions about the above questions were asked in two categories consisting on 0 and 01,0 l both Zero and one consisted on multiple choice, answer of zero representing positive and one negative actions. The positive percentage of Fatima Bhutto's Fans out of hundred of questions of following serial no were respectively $60 \%, 61 \% 73 \%, 40 \%$ and $21 \%$. If we compare the same questions, the positive percentage of Karzai's fans is respectively $61 \%$, $30 \%, 68 \%, 18 \%$ and $21 \%$.consequently the fans of Fatima Bhutto are more positively. The results are almost same as per general reputation of role model Fatima Bhutto and Karzai. Both have fans little bit same personality according their own personality.

\section{Results and discussions}

- Ideal personality changes our thoughts.

- Thoughts making actions

- When Ideal personality changes our thoughts, their thoughts becomes our thoughts, are two thoughts become one thought.

- If anyone is fan of a person who have bad qualities, participation of that person in economy will not only zero but it will also negative, if any one's ideal is man of 
qualities the fan will left a good impact on economy, followers of fan will also give fruitful result for economy. An ideal person is not a jock, impact of his personality works as a multiplier. An ideal person generates an endless chain of people who follow him. if media or any other source don't highlights the reality of bad famous person, its results will very harmful not only for ,himself $r$ herself, society but also for economy. Impact of ideal effect on fans works very slowly but with respect of time it brings large results.

- As bribery corruption violence etc are bad for economy and human life, and on international level different union, parties united nation discourage such type of evil. There should be a system to stop the distortion of innocent peoples, society and economy.

- Almost everyone loves with someone, focus and idealize a personality. Famous people become ideal, their fans idealize them by ignoring and becoming careless about the famous personalities good or bad qualities their should be a system to highlight the famous person, are man of qualities, when media and union on international system will make more popular to a just famous person, when majority know them the man of qualities will attract majority and remaining minority will go to idealize other different persons or personalities.

- Mostly young blood impressed and idealize famous person. if we compare the ratio of young and elder fans. Average of young fans is 70 time grater than elder and match person. There is another important point that those fan who are young and not fully mach, some time they idealize the person just because of style, when they try to adopt their style and they mostly think about than slowly they start to love with ideal more and more just because of thinking and touching with them with respect of time they become crazy and adopt not only style but also qualities. For example when a person start to eat a slice ,every bite start to fill his stomach .every coming day make the strong relation of fan with ideal if he don't stop to think about him and seeing, reading and listening him. if ideal is not good results of fans life and economy will destroy.

\section{Recommendations}

- Politician should be good persons, otherwise they leads fans towards distortion.

- There should be trainings for politicians for saving country and people, because fans follow them.

- As bribery corruption violence etc are bad for economy and human life, and on international level different union, parties united nation discourage such type of evil through different ways. There should be a system to stop the distortion of innocent peoples, society and economy on international system. If on international unions adopt a system to list a person who not a man of good qualities media automatically highlight him or her.

- Almost everyone loves with someone, focus and idealizes a personality. Famous 
people become ideal, their fans idealize them by ignoring and becoming careless about the famous personality's good or bad qualities there should be a system to highlight the famous person, are man of qualities, when media and union on international system will make more popular to a just famous person, when majority know them the man of qualities will attract majority and lifted minority will go to idealize other different persons or personalities.

\section{References}

Abney, R. (1991). Recruiting and mentoring sport leaders. Journal of Physical Education, Recreation and Dance, 62, 48-56.

Bandura, A. (1986). Social foundations of thought and action: A social cognitive theory. Englewood Cliffs, NJ: Prentice-Hall.

Clark, D. G., Blair, S. N., \& Culan, M. R. (1988). Are HPE teachers good role models. Journal of Physical Education, Recreation and Dance, 59(7), 76-80.

DeFrancesco, C., \& Johnson, P. (1997). Athlete and parent perceptions in junior tennis. Journal of Sport Behavior, 20, 29-36.

Landers, D. M., \& Landers, D. M. (1973). Teacher versus peer models: Effect of models presence and performance level on motor behavior. Journal of Motor Behavior, 5, 129-139.

Lines, G. (2001). Villains, fools or heroes? Sports stars as role models for young people. Leisure Studies, 20(4), 285-304. 